\title{
PENGARUH BRAND IMAGE DAN BRAND TRUST TERHADAP BRAND LOYALTY NASABAH PRUDENTIAL SYARIAH PADA PT. FUTURISTIK ARTHA GEMILANG (Studi kasus di kantor cabang agensi Prudential Syariah PT. Futuristik Artha Gemilang Jakarta Selatan)

\author{
Derita Qurbani*) \\ email : dosen01582@unpam.ac.id \\ Veta Lidya Delimah Pasaribu*)
}

\begin{abstract}
ABSTRAK
Penelitian ini bertujuan untuk mengetahui Brand Image mengetahui Brand Trust mengetahui Brand Loyalty dan seberapa besar Pengaruh Brand Image dan Brand Trust Terhadap Brand Loyalty Nasabah Prudential Syariah pada PT.Futuristik Artha Gemilang Jakarta Selatan.

Metode penelitian bersifat Deskriptif Assosiatif dengan pendekatan Kuantitatif. Populasi dalam penelitian ini adalah Nasabah Prudential Syariah PT.Futuristik Artha Gemilang Jakarta Selatan. Dengan menggunakan sampel jenuh sebanyak 30 responden. Teknik pengumpulan data dengan cara menyebarkan kuesioner dan teknik analisis data adalah Uji Validitas, Uji Reliabilitas, Uji Normalitas, Uji Heteroskedastisitas, Analisis Regresi Linier Berganda, Uji Hipotesis Parsial Koefisien (Uji t) dan Uji Hipotesis Parsial Koefisien (Uji f).

Dari hasil olah data yang diperoleh uji t variabel Brand Image memiliki t hitung lebih kecil dari t tabel yaitu $0,369<2,051$ dan nilai signifikasi $0,725>0,05$ artinya variabel Brand Image tidak berpengaruh signifikan terhadap Brand Loyalty sedangkan Brand Trust memiliki angka $\mathrm{t}$ hitung lebih besar dari t tabel yaitu 9,479>2,051 dan nilai signifikasi $0,000<0,05$ artinya variabel Brand Trust berpengaruh signifikan terhadap Brand Loyalty. Dari hasil penelitian di dapat hasil uji f 46,945>3,35 dan nilai signifikasi $0,000<0,05$ sehingga dapat disimpulkan bahwa Brand Image dan Brand Trust secara simultan berpengaruh signifikan terhadap Brand LoyaltyNasabah Prudential Syariah.
\end{abstract}

\section{Kata Kunci : Brand Image,Brand Trust,Brand loyalty}

\section{ABSTRACT}

This study aims to find out the Brand Image knows the Brand Trust knows Brand Loyalty and how much the Influence of Brand Image and Brand Trust on Prudential Syariah Brand Loyalty Customers at PT.Futuristik Artha Gemilang, South Jakarta.

The research method used is descriptive associative with a quantitative approach. The population in this study is Prudential Syariah Customer PT.Futuristik Artha Gemilang, South Jakarta. By using saturated samples as many as 30 respondents. Data collection techniques by distributing questionnaires and data analysis techniques are Validity Test, Reliability Test, Normality Test, Heteroscedasticity Test, Multiple Linear Regression Analysis, Partial Coefficient Hypothesis Test (t Test) and Partial Coefficient Hypothesis Test (Test f).

From the results of the data obtained by the $t$ test the Brand Image variable has a $t$ count smaller than $t$ table which is $0.369<2.051$ and a significance value of $0.725>0.05$ means that the Brand Image variable does not significantly affect Brand Loyalty whereas the Brand Trust has a $t$ count greater from $t$ table that is 9,479>2,051 and a significance value of $0,000<0,05$ means that Brand Trust variables have a significant effect on Brand Loyalty. 
From the results of the research, the results of the $f$ test were 46.945> 3.35 and the significance value of $0,000<0.05$ so that it can be concluded that Brand Image and Brand Trust simultaneously have a significant effect on Prudential Syariah Brand Loyalty.

Keyword:brand image, product quality, promotion, buying decisions

\section{A. atar Belakang Masalah}

Untuk memenuhi kebutuhan yang belum pasti dimasa yang akan datang maka sebagian manusia memerlukan asuransi. Karena asuransi merupakan salah satu buah peradaban manusia dan merupakan suatu hasil evaluasi kebutuhan manusia yang sangat hakiki ialah kebutuhan akan rasa aman dan terlindung, terhadap kemungkinan menderita kerugian. Namun tidak semua manusia memahami seberapa pentingnya asuransi untuk kehidupan pada zaman sekarang ini, untuk itu tenaga pemasar asuransi memiliki beberapa carauntuk dapat memberikan Brand Image dan juga Brand Trustyang dapat meningkatkan Brand Loyalty.

Menurut The American Marketing Association (AMA) definisi merek adalah nama, istilah, tanda, symbol dan desain, untuk mengidentifikasikan barang dan jasa dari satu penjual atau kelompok penjual dan untuk membedakan mereka dari para pesaing. Peran merek bukan lagi sekedar nama atau pembeda dengan produk kompetitor, tetapi sudah menjadi salah satu faktor penting dalam keunggulan bersaing. Merek menjadi faktor utama suksesnya sebuah produk. Oleh karena itu perusahaan sangat memperhatikan aktivitas membangun dan memperluas merek. Semua itu dilakukan untuk menciptakan pelanggan yang setia kepada produk tersebut.

Sebagai negara dengan pertumbuhan ekonomi tertinggi yang mencapai 6,3 persen di kawasan Asia Tenggara pada tahun 2011 serta sebagai negara berpenduduk Muslim terbesar, Indonesia memiliki peluang yang sangat besar di dunia bisnis asuransi jiwa syariah. Berdasarkan data dari Kementerian Keuangan, dalam kurun waktu lima tahun, pasar asuransi syariah tumbuh sebesar 53 persen, yaitu 
mencapai Rp 7,3 triliun. Sementara hingga akhir tahun lalu, asuransi syariah mencetak premi sebesar Rp4,97 triliun atau tumbuh 34,9\% dibandingkan tahun sebelumnya. Pertumbuhan terkini juga dapat dilihat dari total pemasukan premi syariah dari PT Prudential Life Assurance (Prudential Indonesia) yang mencapai Rp997,9 miliar, naik 24,2 persen, sampai 30 Juni 2012 dibanding periode yang sama di tahun 2011.

Menyadari potensi perkembangan pasar yang besar serta mendengarkan kebutuhan konsumen untuk mendapatkan proteksi jiwa yang didasari oleh prinsip-prinsip syariah, Prudential Indonesia mengembangkan unit bisnis syariahnya sejak tahun 2007. PT.Prudential Life Assurance (Prudential Indonesia) didirikan pada tahun 1995, PT Prudential Life Assurance (Prudential Indonesia) merupakan bagian dari Prudential, grup jasa keuangan asal Inggris dengan pengalaman lebih dari 160 tahun. Dengan menggabungkan pengalaman internasional Prudential di bidang asuransi jiwa dengan pengetahuan tata cara bisnis lokal, Prudential Indonesia memiliki komitmen untuk mengembangkan bisnisnya di Indonesia. Sejak meluncurkan produk asuransi yang dikaitkan dengan investasi (unit link ) pertamanya di tahun 1999, Prudential Indonesia merupakan pemimpin pasar untuk produk tersebut di Indonesia. Di samping itu, Prudential Indonesia juga menyediakan berbagai produk yang dirancang untuk memenuhi dan melengkapi setiap kebutuhan.

Dari data terakhir per 30 Juni 2012, Prudential Indonesia memiliki kantor pusat di Jakarta dan kantor pemasaran di Medan, Surabaya, Bandung, Denpasar, Batam dan Semarang dengan lebih dari 279 kantor keagenan (termasuk di Jakarta, Surabaya, Medan, Bandung, Yogyakarta, Batam dan Bali). Prudential Indonesia memiliki lebih dari 181.000 jaringan tenaga pemasaran yang melayani lebih dari 1,5 juta nasabah. Tabel dibawah ini juga membuktikan 5 deretan perusahaan asuransi paling banyak followers versi Instagram, dimana Prudential menempati urutan pertama.

Tabel 1.1

Jumlah followersterbanyak versi Instagram Mei 2018 


\begin{tabular}{|l|l|l|}
\hline No & Assurance Brand & Followers \\
\hline 1 & Prudential & $24.8 \mathrm{~K}$ \\
\hline 2 & AlA Indonesia & $14.2 \mathrm{~K}$ \\
\hline 3 & Allianz & $12.2 \mathrm{~K}$ \\
\hline 4 & AXA & $11.9 \mathrm{~K}$ \\
\hline 5 & Jiwasraya & $10.6 \mathrm{~K}$ \\
\hline
\end{tabular}

Sumber :www.instagram.com

\section{B. Rumusan Masalah}

1. Bagaimana gambaran Brand Image Prudential Syariah di kantor cabang agensi PT. Futuristik Artha Gemilang?

2. Bagaimana gambaran Brand Trust Prudential Syariah di kantor cabang agensi PT. Futuristik Artha Gemilang?

3. Bagaimana gambaran Brand Loyalty Prudential Syariah di kantor cabang agensi PT. Futuristik Artha Gemilang?

4. Seberapa besar pengaruh Brand Image terhadap Brand Loyalty nasabah Prudential Syariah ?

5. Seberapa besar pengaruh Brand Trust terhadap Brand Loyalty nasabah Prudential Syariah ?

6. Seberapa besar pengaruh Brand Image dan Brand Trust terhadap Brand Loyaltynasabah Prudential Syariah?

\section{Tujuan Penelitian}

1. Untuk menganalisis gambaran Brand Image Prudential Syariah di kantor cabang agensi PT. Futuristik Artha Gemilang.

2. Untuk menganalisis gambaran Brand Trust Prudential Syariah di kantor cabang agensi PT. Futuristik Artha Gemilang.

3. Untuk menganalisis gambaran Brand Loyalty Prudential Syariah di kantor cabang agensi PT. Futuristik Artha Gemilang. 
4. Untuk menganalisis pengaruh Brand Image dan Brand Trust terhadap Brand Loyalty nasabah Prudential Syariah di kantor cabang agensi PT. Futuristik Artha Gemilang.

\section{Landasan Teori}

\section{Brand Image}

Dalam Sangadji dan Sopiah (2013:327) mengatakan bahwa, "Citra merek (brand image) dapat dianggap sebagai jenis asosiasi yang muncul di benak konsumen ketika mengingat sebuah merek tertentu. Asosiasi tersebut secara sederhana dapat muncul dalam bentuk pemikiran atau citra tertentu yang dikaitkan dengan suatu merek, sama halnya ketika kita berpikir mengenai orang lain." Sangadji dan Sopiah (2013:327) berpendapat bahwa, "Citra merek dapat positif atau negatif, tergantung pada persepsi seseorang terhadap merek."

Indikator Brand Image

Indikator yang digunakan untuk mengukur Citra Merek adalah indikator yang disebutkan oleh Aaker dialih bahasakan oleh Aris Ananda (2010:10) yang mana penjelasan masing-masing indikator tersebut adalah sebagai berikut :

1. Recognition (pengakuan)

2. Reputation (reputasi)

3. Affinity (afinitas)

4. Domain (kedudukan)

\section{Brand Trust}

Dalam (Dahlen, 2012) The American Marketing Association mendefinisikan Brand Loyalty (loyalitas merek) sebagai situasi di mana konsumen umumnya membeli produk atau jasa dengan produsen yang berasal sama daripada membeli dari beberapa pemasok dalam kategori (definisi sales promotion). 
Indikator Brand Trust

Indikator yang mengacu pada Ferrinadewi, dalam Danny Alexander Bastian (2014:2) mengemukakan, terdapat tiga aktivitas yang dapat dilakukan oleh perusahaan untuk menumbuhkan kepercayaan konsumen yaitu :

1. Achieving result (Pemenuhan janji konsumen)

2. Acting with integrity (Bertindak dengan integritas)

3. Demonstrate concern (kepedulian)

\section{Brand Loyalty}

Dalam (Dahlen, 2012) The American Marketing Association mendefinisikan Brand Loyalty (loyalitas merek) sebagai situasi di mana konsumen umumnya membeli produk atau jasa dengan produsen yang berasal sama daripada membeli dari beberapa pemasok dalam kategori (definisi sales promotion). Sejauh mana konsumen secara konsisten membeli merek yang sama dalam kelas produk.

Indikator Brand Loyalty

Menurut Oliver (dalam Hurriyati, 2010) loyalitas adalah komitmen pelanggan bertahan secara mendalam untuk berlangganan kembali atau melakukan pembelian ulang produk atau jasa terpilih secara konsisten pada masa yang akan datang, meskipun pengaruh situasi dan usaha-usaha pemasaran berpotensi menyebabkan perubahan perilaku. Griffin (dalam Hurriyati:2010) mengungkapkan ciri pelanggan yang loyal adalah sebagai berikut :

1. Repurchase (pembelian ulang)melakukan pembelian ulang secara teratur.

2. Purchase across product and service lines (melakukan pembelian lini produk yang lainnya).

3. Retention (ingatan)

4. Referral (referensi) 


\section{E. Metodologi}

Jenis penelitian yang digunakan dalam penelitian ini adalah metode asosiatif dengan menggunakan pendekatan kuantitatif. Tujuan dari metode asosiatif ini yaitu untuk mengetahui pengaruh ataupun juga hubungan antara dua variabel atau lebih . Penelitian ini juga menekankan analisisnya pada data-data numeric (angka) yang diolah dengan menggunakan metode statistika.

\section{F. Hasil dan Pembahasan}

Uji Validitas

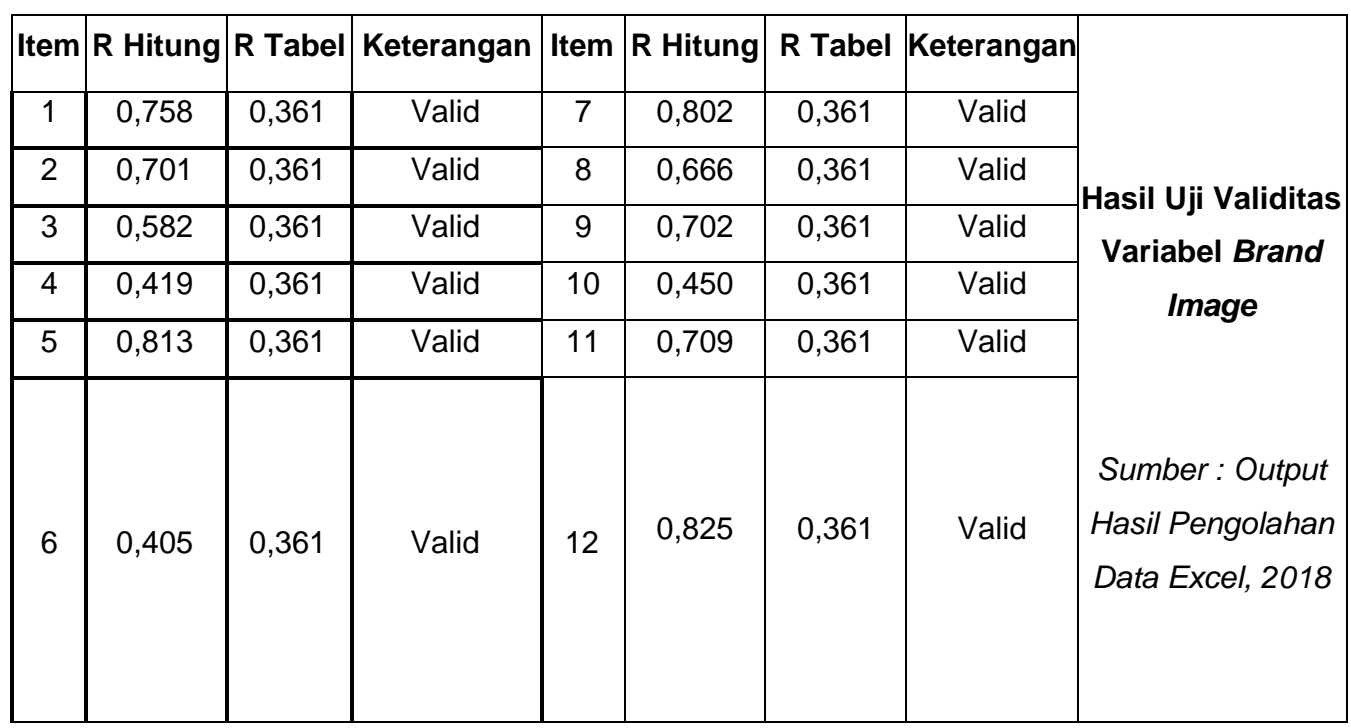

\begin{tabular}{|c|c|c|c|c|c|c|c|}
\hline Item & $\mathbf{R}$ Hitung & $\mathbf{R}$ Tabel & Keterangan & Item & $\mathbf{R}$ Hitung & $\mathbf{R}$ Tabel & Keterangan \\
\hline 1 & 0,691 & 0,361 & Valid & 6 & 0,854 & 0,361 & Valid \\
\hline 2 & 0,676 & 0,361 & Valid & 7 & 0,799 & 0,361 & Valid \\
\hline 3 & 0,884 & 0,361 & Valid & 8 & 0,860 & 0,361 & Valid \\
\hline 4 & 0,428 & 0,361 & Valid & 9 & 0,747 & 0,361 & Valid \\
\hline 5 & 0,819 & 0,361 & Valid & Sumber : Output Hasil Pengolahan Data \\
& & & & \multicolumn{5}{|c|}{ Excel, 2018 } \\
\hline
\end{tabular}




\begin{tabular}{|c|c|c|c|c|c|c|c|c|}
\hline Item & R Hitung & R Tabel & Keterangan & Item & R Hitung & R Tabel & Keterangan & \multirow{7}{*}{$\begin{array}{c}\text { Hasil Uji Validitas } \\
\text { Variabel Brand } \\
\text { Loyalty }\end{array}$} \\
\hline 1 & 0,692 & 0,361 & Valid & 7 & 0,642 & 0,361 & Valid & \\
\hline 2 & 0,458 & 0,361 & Valid & 8 & 0,411 & 0,361 & Valid & \\
\hline 3 & 0,558 & 0,361 & Valid & 9 & 0,579 & 0,361 & Valid & \\
\hline 4 & 0,60 & 0,361 & Valid & 10 & 0,526 & 0,361 & Valid & \\
\hline 5 & 0,801 & 0,361 & Valid & 11 & 0,646 & 0,361 & Valid & \\
\hline 6 & 0,503 & 0,361 & Valid & 12 & 0,742 & 0,361 & Valid & \\
\hline
\end{tabular}

Berdasarkan hasil output diatas menunjukan bahwa keseluruhan item yang diuji memiliki nilai $r$ hitung lebih besar dari $r$ tabel dan dapat dikatakan itemitem tersebut sudah valid dan boleh digunakan untuk proses pengolahan data berikutnya.

\section{Uji Reliabilitas}

\section{Hasil Uji Reliabilitas Variabel Brand Image}

\begin{tabular}{|r|r|}
\hline Cronbach's Alpha & N of Items \\
\hline .879 & 12 \\
\hline
\end{tabular}

\section{Hasil Uji Reliabilitas Variabel Brand Trust \\ Reliability Statistics}

\begin{tabular}{|r|r|}
\hline Cronbach's Alpha & N of Items \\
\hline .899 & 9 \\
\hline
\end{tabular}

Hasil Uji Reliabilitas Variabel Brand Loyalty 


\section{Reliability Statistics}

\begin{tabular}{|r|r|}
\hline Cronbach's Alpha & N of ltems \\
\hline .835 & 12 \\
\hline
\end{tabular}

Seperti yang terlihat pada tabel di atas nilai Cronbach's Alpha yang diperoleh adalah 0,879:0,899: dan 0,835, karena nilai tersebut $>0,60$ maka dapat dikatakan baik atau reliable (jawaban responden yaitu konsisten sehingga dapat dijadikan sebagai alat ukur dalam mengukur variabel penelitian).

\section{Uji Uji Hipotesis Parsial Koefisien Uji t (Parsial)}

Uji Hipotesis Parsial Koefisien (Uji t)

\begin{tabular}{|c|c|c|c|c|c|}
\hline \multicolumn{7}{|c|}{ Coefficients } \\
Model & $\begin{array}{c}\text { Unstandardized } \\
\text { Coefficients }\end{array}$ & $\begin{array}{c}\text { Standardized } \\
\text { Coefficients }\end{array}$ & $\mathbf{t}$ & Sig. \\
& B & Std. Error & Beta & & \\
(Constant) & 18.482 & 5.515 & & 3.351 & .002 \\
Brand image & -.033 & .089 & -.034 & -.369 & .715 \\
Brand trust & .856 & .090 & .875 & 9.479 & .000 \\
\hline
\end{tabular}

a. Dependent Variable: Brand Loyalty

Sumber : Output Hasil Pengolahan Data SPSS V.22.0, 2018

Dari hasil uji t diatas dapat disimpulkan bahwa :

1. Diketahui pada Brand Image memiliki nilai t hitung $(0,369)$ t tabel $(2,051)$ dan nilai signifikasi sebesar $(0,725)>(0,05)$ maka Ho diterima dan Ha ditolak sehingga dapat disimpulkan bahwa Brand Image secara parsial tidak berpengaruh signifikan terhadap Brand Loyalty.

2. Diketahui pada Brand Trust memiliki nilai t hitung $(9,479)>t$ tabel $(2,051)$ dan nilai signifikasi sebesar $(0,00<(0,05)$ maka Ho ditolak dan $\mathrm{Ha}$ diterima sehingga dapat disimpulkan bahwa Brand Trust secara parsial berpengaruh signifikan terhadap Brand Loyalty. 


\section{Uji F (Simultan)}

\section{Uji Hipotesis Parsial Koefisien (Uji f)}

a

ANOVA

\begin{tabular}{|c|c|c|c|c|r|}
\hline \multicolumn{1}{|c|}{ Model } & Sum of Squares & Df & Mean Square & F & Sig. \\
\hline Regression & 619.281 & 2 & 309.641 & 46.945 & .000 \\
Residual & 178.086 & 27 & 6.596 & & \\
Total & 797.367 & 29 & & & \\
\hline
\end{tabular}

a. Dependent Variable: Brand Loyalty

b. Predictors: (Constant), Brand trust, Brand image

Sumber : Output Hasil Pengolahan Data SPSS V.22.0, 2018

Dari tabel 4.15 dapat terlihat bahwa nilai $F$ hitung sebesar 46,945 dengan nilai Sig 0.000 karena nilai Sig lebih kecil dari 0,05 dan $F$ hitung $>F$ tabel $(46,945$ $>3,35$ ) maka Ho ditolak dan Ha diterima sehingga dapat disimpulkan bahwa Brand Image dan Brand Trust secara simultan berpengaruh signifikan terhadap Brand Loyaltynasabah Prudential.

\section{Uji Regresi Linear Berganda}

Hasil Analisis Regresi Linear Berganda-Metode Enter

\begin{tabular}{|c|c|c|c|c|c|}
\hline & & & a & & \\
\hline & & & efficients & & \\
\hline \multirow{3}{*}{ Model } & \multirow{2}{*}{\multicolumn{2}{|c|}{$\begin{array}{l}\text { Unstandardized } \\
\text { Coefficients }\end{array}$}} & Standardized & \multirow{3}{*}{$\mathbf{t}$} & \multirow{3}{*}{ Sig. } \\
\hline & & & Coefficients & & \\
\hline & B & Std. Error & Beta & & \\
\hline \multirow[t]{2}{*}{ (Constant) } & \multirow{3}{*}{18.482} & \multirow{3}{*}{5.515} & & \multirow{3}{*}{.351} & \multirow{3}{*}{002} \\
\hline & & & & & \\
\hline \multirow{2}{*}{ Brand image } & & & & & \\
\hline & -.033 & .089 & -.034 & \multirow{2}{*}{.369} & \multirow{2}{*}{715} \\
\hline \multirow{2}{*}{ Brand trust } & & & & & \\
\hline & 856 & .090 & .875 & .479 & 000 \\
\hline
\end{tabular}

a. Dependent Variable: Brand Loyalty 
Penjelasan persamaan regresi berganda di atas adalah sebagai berikut:

1. Koefisien regresi variabel Brand Image sebesar -0,033. Artinya jika Brand Image mengalami penurunan satu satuan, maka Brand Loyalty akan mengalami penurunan sebesar $-0,033$ satuan dengan asumsi variabel independen lainnya bernilai tetap.

2. Koefisien regresi variabel Brand Trust sebesar 0,856 Artinya jika Brand Trust mengalami kenaikan satu satuan, maka Brand Loyalty akan mengalami kenaikan sebesar 0,856 satuan dengan asumsi variabel independen lainnya bernilai tetap.

Berdasarkan tabel 4.20 dapat dilihat variabel Brand Image memiliki nilai Sig $(0,715)>$ dari $(0,05)$ maka variabel Brand Image dinyatakan tidak memiliki pengaruh signifikan terhadap variabel Brand Loyalty,dan variabel Brand Trust memiliki nilai Sig $(0,000)<$ dari $(0,05)$ maka variabel Brand Trust dinyatakan memiliki pengaruh signifikan terhadap variabel Brand Loyalty.

\section{Uji Normalitas}

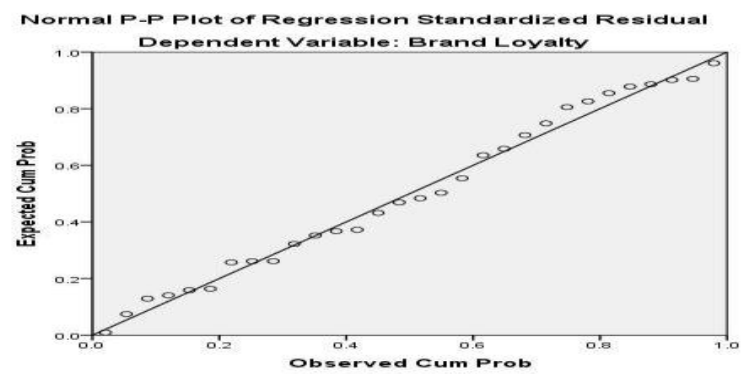

Gambar 4.6 Hasil Uji Normalitas

Sumber : Output Hasil Pengolahan Data SPSS V.22.0, 2018

Pada Gambar 4.6 memperlihatkan bahwa semua data berditribusi normal yang dilihat dari titik-titik data menyebar disekitar garis diagonal dan penyebaran titik-titik data searah dengan garis diagonal. Jadi, dapat dikatakan data variabel berdistribusi secara normal. 


\section{Uji Heterokedastisitas}

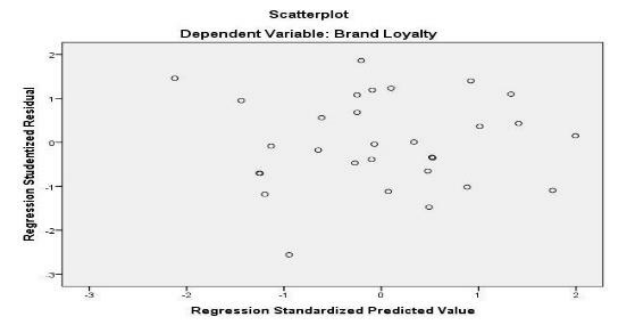

Gambar 4.7 Hasil Uji Heteroskedastisitas

Sumber : Output Hasil Pengolahan Data SPSS V.22.0, 2017

Dari scatterplot tersebut, terdapat bahwa titik-titik menyebar secara acak, baik di bagian atas angka nol atau di bagian bawah angka nol dari sumbu vertikal atau sumbu Y. Dengan demikian, dapat disimpulkan bahwa tidak terjadi heterokedastisitas dalam model regresi ini.

\section{G. Kesimpulan}

1. Berdasarkan data yang terkumpul dari data olahan hasil kuesioner yang dapat dilihat pada tabel 4.2 bahwa Brand Image pada kantor cabang agensi Prudential PT.Futuristik Artha Gemilang sudah tergolong cukup baik namun perlu ditingkatkan lagi. Hal tersebut cerminan dari jawaban responden yang Sangat Setuju dan Setuju $(S S+S)=14 \%+51 \%=65 \%$ sedangkan Ragu-Ragu, Tidak Setuju dan Sangat Tidak Setuju (R+TS+STS) $33 \%+2 \%+0 \%=35 \%$.

2. Berdasarkan data yang terkumpul dari data olahan hasil kuesioner yang dapat dilihat pada tabel 4.4 bahwa Brand Trust pada kantor cabang agensi Prudential PT.Futuristik Artha Gemilang sudah tergolong sangat baik namun tetap perlu dipertahankan dan ditingkatkan. Hal tersebut cerminan dari jawaban responden yang Sangat Setuju dan Setuju $(S S+S)=19 \%+$ $50 \%=69 \%$ sedangkan Ragu-Ragu, Tidak Setuju dan Sangat Tidak Setuju (R+TS+STS) $26 \%+5 \%+0 \%=31 \%$.

3. Berdasarkan data yang terkumpul dari data olahan hasil kuesioner yang dapat dilihat pada tabel 4.6 bahwa Brand Loyalty pada kantor cabang agensi Prudential PT.Futuristik Artha Gemilang sudah tergolong baik namun perlu dipertahankan dan ditingkatkan lagi. Hal tersebut cerminan 
dari jawaban responden yang Sangat Setuju dan Setuju $(S S+S)=19 \%+$ $51 \%=70 \%$ sedangkan Ragu-Ragu, Tidak Setuju dan Sangat Tidak Setuju (R+TS+STS) $28 \%+2 \%+0 \%=30 \%$.

4. Diketahui pada Brand Image memiliki nilai t hitung $(0,369)<t$ tabel $(2,051)$ dan nilai signifikasi sebesar $(0,725)>(0,05)$ maka Ho diterima dan $\mathrm{Ha}$ ditolak sehingga dapat disimpulkan bahwa Brand Image secara parsial tidak berpengaruh signifikan terhadap Brand Loyalty.

5. Diketahui pada Brand Trust memiliki nilai t hitung $(9,479)>t$ tabel $(2,051)$ dan nilai signifikasi sebesar $(0,00<(0,05)$ maka Ho ditolak dan Ha diterima sehingga dapat disimpulkan bahwa Brand Trust secara parsial berpengaruh signifikan terhadap Brand Loyalty.

6. Diketahui nilai $F$ hitung sebesar 46,945 dengan nilai Sig 0.000 karena nilai Sig lebih kecil dari 0,05 dan $F$ hitung $>F$ tabel $(46,945>3,35)$ maka Ho ditolak dan Ha diterima sehingga dapat disimpulkan bahwa Brand Image dan Brand Trust secara simultan berpengaruh signifikan terhadap Brand Loyaltynasabah Prudential.

\section{H. Daftar Pustaka}

Anzil Laila, Triyonowati. 2017. Pengaruh Kepercayaan dan Komitmen Terhadap Loyalitas Konsumen PT.JNE Surabaya. Jurnal IImu dan Riset Manajemen Vol 6 No 6 1-17.

Danny Alexander Bastian. 2014. Analisa Pengaruh Citra Merek (Brand Image) dan Kepercayaan Merek (Brand Trust) Terhadap Loyalitas Merek (Brand Loyalty) ADES PT. Ades Alfindo Putra Setia. Jurnal Manajemen Pemasaran Petra Vol 2 No 1, 1-9.

Fitri Anggraini, Ruzikna. 2015. Pengaruh Brand Image Terhadap Loyalitas Pelanggan Pada Koran Harian Riau Pos. Vol 3 No.1 No 1-17.

Ghozali, Imam. 2013. Aplikasi Analisis Multivariate dengan Program IBM SPSS 21 Update PLS Regresi. Edisi 7. Universitas Diponegoro. Semarang. 
Hermawan, Agus. 2012. Komunikasi Pemasaran. Erlangga, Jakarta.

Hurriyati Ratih, Dr., M.Si, 2010, "Bauran Pemasaran dan Loyalitas Konsumen".

Jakarta: Alfabeta CV.

Jihad Kamilullah, Ari Kusyanti, Himawat Aryadita. 2018. Analisis

Pengaruh Kepercayaan, Kepuasan, dan Reputasi Terhadap Loyalitas Konsumen Online Shop Dalam Pembelian Produk di Toko XYZ. Jurnal Pengembangan Teknologi Informasi dan IImu Komputer. Vol 2 No 7 2660-2669.

Kotler \& Keller. (tanpa tahun). Manajemen Pemasaran. Jakarta :Erlangga.

2012, Marketing Management Edisi 14, Global Edition. Pearson Prentice Hall.

, 2007, Manajemen Pemasaran, Edisi Kedua Belas, Jilid 1, dialihbahasakan oleh Benjamin Molan, Jakarta: PT.Indeks.

Kotler, P, and Amstrong, G. 2012. Principles of Marketing. 14 ${ }^{\text {th }}$ edition. New Jersey : Pearson : Prentice Hall.

Mohammad Rizan, Basrah Saidani, Yusiyana Sari. 2012. Pengaruh Brand Image dan Brand Trust terhadap Brand Lotalty The Botol Sosro Food Court ITC Cempaka Mas. Jurnal Riset Manajemen Sains Indonesia (JRMSI) Vol 3 No 11-17.

Mitha Fadilla, Noor. November 2014. Pengaruh Brand Image dan Brand Trust Terhadap Brand Loyalty King Thai Tea Bandung. Program Magister

Manajemen Fakultas Ekonomi Vol III No 2.

Puspita sari Novi.2015. Manajemen Asuransi Syariah. Yogyakarta : UII Press. 
Priyatno Duwi. 2013. Mandiri Belajar Analisis Data Dengan SPSS. Yogyakarta :Mediakom.

Priyatno, Duwi. 2014. SPSS 22 Pengolahan Data Terpraktis. Andi. Yogyakarta. Stoner, Freeman dan Gilbert (1995). Pengantar Bisnis. Graha Ilmu. Yogyakarta

Sugiyono. 2013 Metode Penelitian Pendidikan Pendekatan Kuantitatif, Kualitatif, dan R\&D. Bandung: Alfabeta. , Metode Penelitian Manajemen. Alfabeta. Bandung

-----------------, Metode Penelitian Bisnis, Alfabeta. Bandung https://marketing.co.id/brand-loyalty/

https://media.neliti.com/media/publications/62944-ID-none.pdf https://media.neliti.com/media/publications/62944-ID-none.pdf https://youtu.be/txn-kclWEuk https://youtu.be/gZ00bUyuDq0 